\title{
CONSUMERS'S WILLINGNESS TO PAY FOR AVOIDING SALMONELLA INFECTION
}

\author{
Á. VAJDA ${ }^{a *}$, Cs. MohÁCSI-FARKAS ${ }^{b}$, L. ÓZSVV́RI ${ }^{a}$ and Gy. KASZa ${ }^{c}$ \\ ${ }^{\text {a}}$ University of Veterinary Medicine, H-1078 Budapest, István utca 2. Hungary \\ ${ }^{b}$ Department of Food Microbiology and Biotechnology, Faculty of Food Science, Szent István University \\ H-1118 Budapest, Villányi út 29-43. Hungary \\ ${ }^{\mathrm{c}}$ National Food Chain Safety Office, H-1024 Budapest, Keleti Károly utca 24. Hungary
}

(Received: 28 May 2019; accepted: 5 August 2019)

\begin{abstract}
Salmonellosis is a widely known infectious disease in Hungary that played dominant role between 1960 and 1996 and remained one of the top food-borne illnesses to these days with an estimated total number of 96048 cases (2019). Beside direct costs of treatment, indirect costs are also significant on the level of population. Among indirect costs, consumer well-being losses are difficult to be estimated. For this purpose, the willingness to pay (WTP) method is used most frequently that measures the cost an individual would undertake to avoid a certain harm. For the well-being loss estimation, the data of National Food Chain Safety Authority's annual consumer survey was used, in which 323 respondents gave evaluable answer to the open-ended WTP question. Results indicate that an average respondent would pay 18.6 EUR to avoid salmonellosis. Main factors affecting WTP were size of family and number of children. The numbers indicate that the consumer well-being loss could be about 1786060 EUR annually, resulting from the multiplication of the estimated number of annual salmonellosis cases and the average WTP value. It can be concluded that consumer well-being losses alone would call for further interventions in Salmonella eradication, not to mention other - more direct - cost elements.
\end{abstract}

Keywords: willingness to pay, avoiding risk, salmonellosis, consumer study, food safety

Salmonella infection generally causes fever and diarrheal symptoms. Infections are mainly due to contaminated food (poultry, pork, raw eggs, etc.) consumption, which are incorrectly stored, but it may also be due to contact with an infected person or failure to comply with hygiene rules (AZEVEDO et al., 2014).

Based on national statistics, the number of human salmonellosis continuously increased (a maximum of 28000 cases per year) from 1960 to 1996 and has become one of the major public health threats for decades in Hungary (SzeITzNÉ et al., 2008). Therefore, this type of infection has become the best-known foodborne disease among the population. Even if the number of cases decreased from 1997, salmonellosis has remained one of the most important zoonotic diseases up to these days. While campylobacteriosis started to play a leading role in epidemiologic reports from 2004, Salmonella is still more widely known among the Hungarian population. While a simple google search delivers 13100 hits for the Hungarian word for salmonellosis, a similar search in regard of campylobacteriosis only results in 534 .

Compared to the average EU rate in 2004 and 2008, Hungarian rates of confirmed cases were three times higher (74.7 and 66.1 vs. 42.2 and 26.4 per 100 000) (KASZA et al., 2011). In 2017, when an increasing tendency was noted in many EU member states including Hungary, the rate of confirmed cases was two times higher than the EU average (40.0 vs. 19.7

\footnotetext{
* To whom correspondence should be addressed.

Phone: + 3630642 7297; e-mail: vajda.agnes@univet.hu
} 
cases per 100 000) (ECDC-EFSA, 2018). In reality, however, the number of salmonellosis cases may be even higher. Based on a population survey (VAJDA et al., 2019), approximately 18 times more individuals are suffering from Salmonella infection than it is officially recorded in the national epidemiological database.

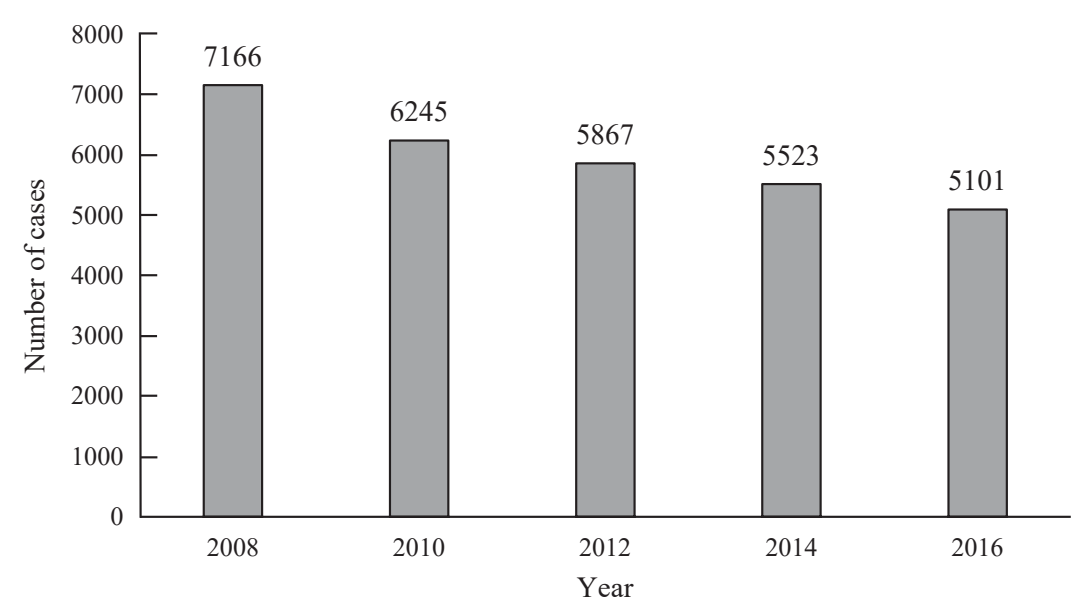

Fig. 1. Reported number of human salmonellosis in Hungary, 2008-2016 Source: Own compilation based on data of HCSO (2019)

In Hungary, the first guideline for reducing the level of Salmonella contamination was compiled and published by the Salmonella sub-committee of the Hungarian Academy of Sciences in 1995. In the late 90s, the monitoring of Salmonella Enteritidis and Salmonella Typhimurium had also been established. Following the accession to the EU in 2004, rules of the monitoring procedure had been modified. As mentioned by SzABÁRA and co-workers (2010a), the protection against specified zoonotic agents in animals and products of animal origin was initially based on the Council Directive 92/117/EEC. Further on, regulation is extended by two legal sources: Directive 2003/99/EC on the monitoring of zoonoses and zoonotic agents, as well as Regulation (EC) No. 2160/2003 of the European Parliament and of the Council on the control of Salmonella and other specified food-borne zoonotic agents (EC, 2003a, b).

Based on the registered data, the EU goal was to reduce prevalence of certain Salmonella serotypes to less than $1 \%$ in poultry (breeding and broiler chicken, layer hen, breeding and broiler turkey). In order to achieve these aims, according to the Regulation (EC) No. 470/2009 of the European Parliament and of the Council (EC, 2009), the eradication programmes in the Member States were co-financed up to $50 \%$ of the total cost by the EU.

Vaccination of poultry against salmonellosis in the Salmonella eradication program and the improving hygiene in food industry and food trade resulted in the decrease of human cases (SzABÁRA et al., 2010b). However, home-made preparation of food (heat treatment, avoiding cross-contamination) and personal hygiene remained crucial to prevent human infections (Røssvoll et al., 2015).

Salmonellosis causes significant financial losses for households, the healthcare system, and also for businesses (BuzBY et al., 1996, KASzA et al., 2011). The costs of the disease fall into two categories: direct and indirect costs. In terms of eligibility, direct costs primarily 
include healthcare expenditures, while indirect costs consist of loss of income and productivity, as well as the loss of consumer confidence in food safety (Table 1).

There are several methods to examine the social costs of foodborne diseases. One of the most widely used method is the so-called Cost-of-Illness Analysis (COI), developed by Malzberg in 1950 (SCHMIDT \& RodRICK, 2003). Another widely used approach is the Willingness to Pay (WTP) analysis that is based on the principles of welfare economics and measures the willingness of consumers to pay for reducing the risk of becoming ill.

The main aim of this research was to measure the willingness of the Hungarian consumers to pay for avoiding a commonly occurring diarrhoeal disease, salmonellosis. A second objective was to investigate the factors that influence the subjective judgment of the respondents in this matter.

Table 1. Costs of foodborne diseases at social level

\begin{tabular}{|c|c|c|}
\hline Costs to households & Industry costs & $\begin{array}{l}\text { Regulatory and public health sector } \\
\text { costs for foodborne pathogens }\end{array}$ \\
\hline $\begin{array}{l}\text { Human medical costs } \\
\text { - Physician visits, } \\
\text { - Laboratory costs, } \\
\text { - Hospitalization, medications, } \\
\text { - Ambulance or travel costs } \\
\text { Income/productivity loss } \\
\text { - Ill person or deaths, } \\
\text { - Caretaker for ill person } \\
\text { Other direct costs } \\
\text { - Travel costs to visit hospitalized } \\
\text { person, } \\
\text { - Home modifications, } \\
\text { - Vocational/physical rehabilitation, } \\
\text { - Childcare costs } \\
\text { - Institutional care, } \\
\text { - Lost leisure time } \\
\text { Psychological costs } \\
\text { - Pain and other psychological } \\
\text { suffering } \\
\text { - Risk aversion } \\
\text { Preventive behaviour costs } \\
\text { - Extra cleaning/cooking time costs } \\
\text { - Extra cost of refrigerator, freezer, } \\
\text { - Increased food cost (willingness } \\
\text { to pay for more expensive but } \\
\text { safer food to avoid illness), etc. }\end{array}$ & $\begin{array}{l}\text { Costs of animal production } \\
\text { - Morbidity and mortality of } \\
\text { animals on farms, } \\
\text { - Reduced growth rate/feed } \\
\text { efficiency and increased fattening } \\
\text { time, etc. } \\
\text { Costs of disposal of contaminated } \\
\text { animals on farm and at slaughter- } \\
\text { house } \\
\text { - Increased condemnation or extra } \\
\text { treating at slaughterhouse, } \\
\text { - Illness among workers because of } \\
\text { handling contaminated animals or } \\
\text { products, etc. } \\
\text { Control costs for pathogens } \\
\text { - New farm practices } \\
\text { - Altered animal transport and } \\
\text { marketing patterns, } \\
\text { - New slaughterhouse and } \\
\text { processing procedures, } \\
\text { - New wholesale/retail practices, } \\
\text { - Risk assessment modelling by } \\
\text { industry for all links in the food } \\
\text { chain, etc. } \\
\text { Outbreak costs: } \\
\text { - Herd slaughter/product withdraw- } \\
\text { al, } \\
\text { - Plant closings and clean-up, } \\
\text { Regulatory fines, } \\
\text { - Reduced product demand because } \\
\text { of outbreak, } \\
\text { - Increased advertising or consumer } \\
\text { assurances following outbreak, } \\
\text { etc. }\end{array}$ & $\begin{array}{l}\text { Disease surveillance costs } \\
\text { - Monitoring of incidence/severity } \\
\text { of human cases and pathogen } \\
\text { incidence in the food chain, } \\
\text { - Developing integrated database for } \\
\text { foodborne pathogens, etc. } \\
\text { Research } \\
\text { - Identifying new foodborne } \\
\text { pathogens for human illnesses } \\
\text { - Identifying high-risk production } \\
\text { and consumption practices } \\
\text { - Identifying consumers being at } \\
\text { high-risk for certain pathogens } \\
\text { - Developing cheaper and faster } \\
\text { pathogen tests } \\
\text { - Risk assessment modelling for all } \\
\text { links in the food chain } \\
\text { Outbreak costs } \\
\text { - Costs of outbreak investigation, } \\
\text { - Serological testing for diagnosis of } \\
\text { the infection in patients affected by } \\
\text { an outbreak } \\
\text { - Legal actions to enforce } \\
\text { regulations that may have been } \\
\text { violated } \\
\text { Other considerations: } \\
\text { - Distributional effects in different } \\
\text { regions, industries, etc. } \\
\text { - Special considerations for persons } \\
\text { more susceptible to diseases } \\
\text { (young, older adults) }\end{array}$ \\
\hline
\end{tabular}

Source: Own compilation based on BuzBY and co-workers, 1996 


\section{Materials and methods}

\subsection{Consumer survey}

In our work, we used the data of the Hungarian National Food Chain Safety Authority's 2017 survey ( $\mathrm{n}=1001$, personal interviews, representative sampling to age, sex, geographic distribution on NUTS2 level). The question related to willingness to pay to avoid Salmonella infection was answered by 460 persons. However, only numerical or quantifiable answers were taken into account. 'Nothing' or 'I do not want to pay more for safer food' have also been regarded quantifiable answers and meant 0 . Distribution of numerical and quantifiable data was scattered. In order to exclude outliers, the commonly used box-and-whisker plot was applied (SAJTOS \& Mitrev, 2007) that resulted in a threshold value of 20000 HUF (64.7 EUR) maximum (HUF/EUR exchange rate of 2017 was used (HCSO, 2017a)). Finally, the number of analysable WTP answers was 323 (Table 2).

Table 2. WTP respondents by age group, educational level, level of income, and economic status, $\%(\mathrm{n}=323)$

\begin{tabular}{|c|c|c|c|c|c|c|c|}
\hline \multicolumn{2}{|c|}{ Age group } & \multicolumn{2}{|c|}{ Level of education } & \multicolumn{2}{|c|}{ Level of income } & \multicolumn{2}{|c|}{ Economic status } \\
\hline 29 & $29.1(94)$ & Primary school & $2.5(8)$ & Low & $2.2(7)$ & $\begin{array}{l}\text { Employed/ } \\
\text { Self-employed }\end{array}$ & $63.5(205)$ \\
\hline $30-39$ & $24.8(80)$ & Vocational school & $4.6(15)$ & Below average & $10.3(33)$ & Retired & $13.9(45)$ \\
\hline $40-59$ & $28.8(93)$ & Secondary school & $36.2(117)$ & Average & $66.9(214)$ & Job seeker & $3.4(11)$ \\
\hline \multirow[t]{2}{*}{$60+$} & $17.3(56)$ & $\begin{array}{l}\text { University, } \\
\text { college }\end{array}$ & $56.7(183)$ & $\begin{array}{l}\text { Above the } \\
\text { average }\end{array}$ & $19.4(62)$ & Homemaker & $1.9(6)$ \\
\hline & & & & High & $1.3(4)$ & Student & $17.3(56)$ \\
\hline
\end{tabular}

Even if responses ( $\mathrm{n}=68$ ) such as 'Being healthy is worth everything' or 'It is worth a lot' were excluded from the analysis, they also gave useful information on respondents' attitude and assessment. One fifth (13 out of 68) of them stated our question on WTP was meaningless or not answerable, while $16.2 \%$ (11 out of 68 ) said value of health cannot be expressed in monetary values (Fig. 2).

\subsection{Estimation of willingness to pay}

There are several methods to assess consumer WTP. These approaches can be categorised by measuring WTP directly or indirectly and investigating hypothetical or actual WTP. They also differ from each other in the type of questions used in the survey (e.g. open-ended, closeended, or bidding questions) (AIzZUDin et al., 2014).

Our WTP analysis was based on one direct question with a definition. In order to estimate WTP to avoid salmonellosis, respondents had to answer the following question: 'How much would you pay for avoiding a Salmonella infection? (Salmonellosis is an infection, which generally causes diarrhoea, cramps, shivering, and relatively high fever with a recovery time of 3-4 days.)'.

Even if salmonellosis is mainly due to the consumption of a product of animal origin (especially eggs, poultry, meat, milk products), almost any food can become a source of infection. Also, a significant share of Salmonella infection cases are caused by human-human interactions or poor general hygiene. In real life, the source of salmonellosis is often difficult to trace back. Therefore, identification of the source is often based on assumptions (especially if it was a single case without further investigation). Hence, in this paper WTP was not used 
in regard of a specific food category (e.g. how much more you would pay for a Salmonella free egg compared to a normal one) but in a general sense about avoiding one Salmonella infection, with no regard of the cause.

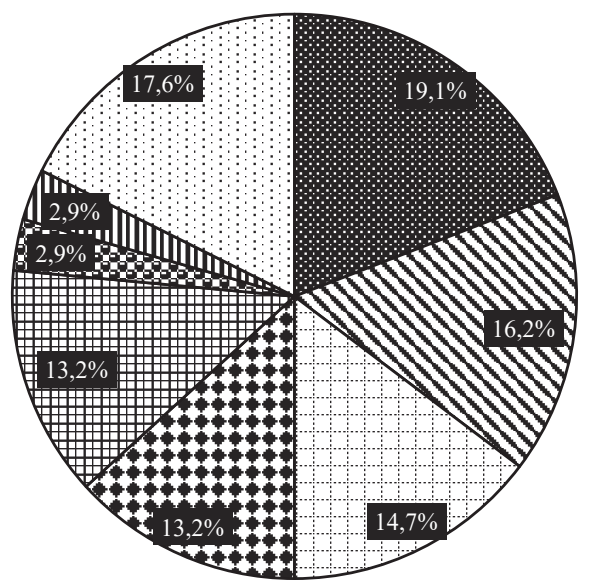

Fig. 2. Categories of unquantifiable WTP responses $(\mathrm{n}=68)$

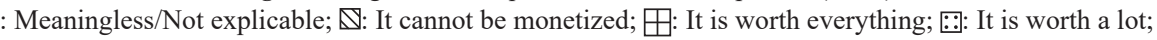
囲: I cannot prejudge/decide; It is worth as much as the price of food, drug and sickness allowance

皿: As much as I can afford myself to pay; Other

\subsection{Statistical analysis}

1.3.1. Crosstabs statistics. WTP is often influenced by demographic parameters (AzIMATUN et al., 2012). In this paper, to highlight relationship between willingness to pay and certain socio-demographic parameters such as gender, education, age, economic status, and geographical region, crosstabs statistics with Pearson's Chi-square test were applied. For statistical evaluation IBM SPSS 22. Software was used.

1.3.2. Factor analysis. Beside socio-demographic variables, we were also interested in the effect of other attributions. Thus, correlations, which were also necessary because of factor analysis, were tested between WTP answers, demographic parameters, and personal attributions (Table 3).

According to Sajtos \& Mitrev (2007), factor analysis is commonly applied to reduce the number of correlated variables and to make the results of socio-economic surveys easier to understand. First, $\mathrm{KMO}$ and Bartlett's Test were used to determine whether our data fit this type of analysis. Since KMO test resulted a value of 0.6 and Bartlett test proved that there were correlations between the variables, our data were considered appropriate to the analysis. As extraction method Principal Component Analysis, as rotation method Varimax rotation procedure were performed. In order to be accepted, the factors had to explain at least $60 \%$ of the total variance and their absolute value had to be equal or higher than 0.5 .

\subsection{Uncertainty analysis}

The amount of money people would pay for avoiding salmonellosis varied considerably. In order to test normality, Kolmogorov-Smirnov and Shapiro-Wilk tests were performed. Test results showed a multimodal distribution in WTP data.

Acta Alimentaria 49, 2020 


\section{Results and discussion}

\subsection{Survey data on Hungarian WTP for safer food}

The mean of consumer WTP of those who would spend money to avoid Salmonella infection was 5746 HUF (18.6 EUR), the median value 5000 HUF and the mode 10000 HUF. We found that 73 out of 323 individuals totally rejected to pay more for avoiding food-borne infections, while 110 of them would have paid 10000 HUF (32.3 EUR) or more, which is at least twice the amount spent on a weekly food-shopping in Hungary.

Table 4. Distribution of WTP on the basis of the amounts $(n=323)$

\begin{tabular}{lcc}
\hline WTP answers, HUF & Number of respondents & Percentage, $\%$ \\
\hline $10001-20000$ & 110 & 34.1 \\
$5001-10000$ & 72 & 22.3 \\
$0-5000$ & 141 & 43.7 \\
\hline Total & 323 & 100.0 \\
\hline
\end{tabular}

\subsection{Relationship between WTP and demographic parameters}

Results obtained from Pearson's chi-square test showed that relationship was significant $(\mathrm{P}=0.000)$ not only between consumer WTP and age groups, but also between WTP and level of education $(\mathrm{P}=0.000)$. Contrary to what we expected, economic status had no effect on consumer WTP $(\mathrm{P}=0.844)$.

\subsection{Main factors affecting Hungarian consumer WTP}

Results from factor analysis showed that our variables, which significantly characterize our respondents, can be described by 5 factors (Table 5). The first factor, which was named 'complexity of the household', included the number of children under the age of 15 and the size of the household. The second group, 'role in the family', consisted of: gender, responsibility for food at home and following a special diet. These parameters generally characterize women. The third factor called 'susceptibility' involved both age group and the fact that respondents had health symptoms like fever, diarrhoea, vomiting, which occurred last year. According to public health data, among age groups younger and elder suffer more often from Salmonella infection (SzEITZNÉ et al., 2008).

Group 4 included only the type of residence, while the last one consisted of the level of income and education. According to scientific literature, there is a general link between these two demographic parameters (RHEE, 2013).

\subsection{Discussion of the results}

Compared to many other countries (FeHER et al., 2016) the number of publications on how much consumers are willing to pay for avoiding certain health risks is very limited in Hungary. Studies on the WTP to avoid any type of zoonotic disease are completely absent up to this day. Our findings give a picture of the Hungarian consumers' willingness to pay for avoiding one of the most frequently occurring zoonotic disease, salmonellosis. Due to the lack of 
similar research in Hungary, comparison of our results with previous national data is not possible. The results show, however, that the age group and higher level of education had a significant effect on consumer WTP. These findings are partially in line with findings of RHEE (2013), who estimated the WTP to avoid a climate change disease. He also found WTP was statistically influenced by the level of income. In our study, in contrast to what we expected, this relationship was not significant. At the same time, respondents could be significantly characterized by 5 main factors, from which the first was the 'complexity of households'. This factor included the number of children under the age of 15 and the size of the household. In his work, RHEE (2013) also stated that higher number of family members under the age of 18 had a positive impact on WTP. Analysis of the effect of demographic factors may give a hint about the segmentation of the society about undertaking food safety risks. However, the ratio of valid responses was lower than expected; only 460 out of 1001 total respondents gave relevant answer. The most important experience was that for many people the notion of expressing health related issues in monetary terms was ethically disturbing or did not make sense at all (assumingly they would need a causal relationship).

Table 5. The main compounds describing variables

\begin{tabular}{|c|c|c|c|c|c|}
\hline Factors & $\begin{array}{l}\text { Complexity } \\
\text { of the } \\
\text { household }\end{array}$ & $\begin{array}{l}\text { Role in the } \\
\text { family }\end{array}$ & Susceptibility & $\begin{array}{c}\text { Living } \\
\text { place }\end{array}$ & $\begin{array}{l}\text { Socio- } \\
\text { economic } \\
\text { status }\end{array}$ \\
\hline $\begin{array}{l}\text { Number of children under } \\
\text { the age of } 15\end{array}$ & -0.870 & & & & \\
\hline Corrected size of household & 0.824 & & & & \\
\hline Gender & & 0.756 & & & \\
\hline $\begin{array}{l}\text { Responsible for buying food } \\
\text { for the family }\end{array}$ & & 0.644 & & & \\
\hline Special diet & & 0.530 & & 0.437 & \\
\hline Age group & & & 0.780 & & \\
\hline $\begin{array}{l}\text { Were you suffering from } \\
\text { fever, diarrhoea, vomiting } \\
\text { last year? }\end{array}$ & & & 0.733 & & \\
\hline Type of residence & & & & 0.800 & \\
\hline Level of income & & & & & 0.874 \\
\hline Level of education & & -0.346 & 0.411 & 0.353 & 0.462 \\
\hline $\begin{array}{l}\text { Cumulative variance } \\
\text { explained }\end{array}$ & 16.391 & 31.037 & 45.439 & 56.622 & 67.802 \\
\hline
\end{tabular}

Extraction method: Principal Component Analysis; rotation method: Varimax with Kaiser normalization Rotation converged in 25 iterations

\section{Conclusions}

Despite the relevance of the subject, no study has been published on consumers' WTP to avoid salmonellosis to date. In our survey we found that the mean of consumer WTP of those who would spend money to avoid Salmonella infection is 5746 HUF (18.6 EUR). This amount of money is close to the average food shopping expenditure per capita per week (5628 HUF/18.2 EUR) in Hungary (HCSO, 2017b). 
However, it is very challenging to express the monetary value of health. Our findings may give an indicator for policy makers about the well-being effect of Salmonella reduction on the population level. In our previous study, estimated total (reported and latent) number of salmonellosis was 96048 cases in average per year (based on the average number of cases 2012-2016, multiplied by a country-specific factor (VAJDA et al., 2019)). Only a 10\% drop would deliver $(96048$ cases $\times 0.1 \times 5746$ HUF $=) 55189180$ HUF $(178606$ EUR $)$ gain in the perceived well-being of the consumers alone.

Considering other factors as well, such as direct cost savings in the public health sector, households and companies, we may conclude that finding and financing further interventions (especially risk communication of household food safety issues) for Salmonella reduction would be beneficial on social level.

The authors thank the generous support of the National Food Chain Safety Office, Hungary for allowing the use of research data for scientific purposes. The study has been also supported by the Doctoral School of Food Sciences of Szent István University, EFOP-3.6.2-16-2017-00012 and SafeConsume project.

\section{References}

Aizzudin, A.N., Sulong, S. \& Aluunid, S.M. (2014): Methods and tools for measuring willingness to pay for healthcare: what is suitable for developing countries? BMC Public Health, 14(S1), 020.

Azevedo, I., Albano, H., Silva, J. \& Teixeira, P. (2014): Food safety in the domestic environment. Food Control, $37,272-274$

Azimatun, N.A., Sulung, S. \& AluUnid, S.M. (2012): Factors influencing willingness to pay for healthcare. BMC Public Health, 12(2), 52-67.

Buzby, J.C., Roberts, T., Jordan Lin, C.-T. \& MacDonald, J.M. (1996): Bacterial foodborne disease: Medical costs and productivity losses. Economic Research Service, USDA. Agricultural Economic Report No. 741, pp. 8-9.

EC (2003a): Directive 2003/99/EC of the European Parliament and of the Council of 17 November 2003 on the monitoring of zoonoses and zoonotic agents, amending Council Decision 90/424/EEC and repealing Council Directive 92/117/EEC. OJ L. 325/31-36.

EC (2003b): Regulation (EC) No 2160/2003 of the European Parliament and of the Council of 17 November 2003 on the control of Salmonella and other specified food-borne zoonotic agents. OJ L 325/1-15.

EC (2009): Regulation (EC) No 470/2009 of the European Parliament and of the Council of 6 May 2009 laying down Community procedures for the establishment of residue limits of pharmacologically active substances in foodstuffs of animal origin. OJ L. 152/11-17.

ECDC-EFSA (2018): The European Union summary report on trends and sources of zoonoses, zoonotic agents and food-borne outbreaks in 2017. EFSA J., 16(12): 5500, pp. 1, 28-29.

Feher, M.D., Brazier, J., Schaper, N., Vega-Hernandez, G., Nikolajsen, A. \& Bøgelund, M. (2016): Patients' with type 2 diabetes willingness to pay for insulin therapy and clinical outcomes. BMJ Open Diabetes Research and Care, 2016, 4:e00192

HCSO (2017a): A nemzeti valuták árfolyama (2007-2018). (Exchange rate of national currencies (2007-2018)). Hungarian Central Statistical Office. Available at https://www.ksh.hu/docs/hun/eurostat_tablak/tabl/tec00033. html (last accessed 10 May 2019)

HCSO (2017b): A háztartások fogyasztása, 2017 (előzetes adatok). (Consumption of households, 2017 (preliminary data). Hungarian Central Statistical Office). Available at https://www.ksh.hu/docs/hun/xftp/stattukor/haztfogy/ haztfogy1712.pdf (last accessed 10 May 2019)

HCSO (2019): A bejelentett fontosabb fertőző megbetegedések száma (2001-). (Number of major communicable diseases reported (2001-)). Hungarian Central Statistical Office Available at https://www.ksh.hu/docs/hun/ xstadat/xstadat_eves/i_feb001.html (last accessed 05 May 2019) 
Kasza, Gy., Szeitzné, Sz.M., Mészáros, L., Oravecz, M., Zoltai, A., .. \& Ózsvíri, L. (2011): Élelmiszer-eredetü megbetegedések Magyarországon, EU-tagságunk tükrében. (Food-borne diseases in Hungary in the light of our EU membership). Magy. Állatorvosok, 133(6), 373.

RHEE, H.C. (2013): Willingness to pay for avoiding infection of climate change diseases, in particular tsutsugamushi disease. Osong Public Health Res. Perspect., 4(1), 16-20.

Røssvoll, E.H., Langsrud, S., Bloomfield, S., Moen, B., Hair, E. \& Møretrø, T. (2015): The effects of different hygiene procedures in reducing bacterial contamination in a model domestic kitchen. J. Appl. Microbiol., 119, 582-593.

SAJtos, L. \& Mitrev, A. (2007): SPSS kutatási és adatelemzési kézikönyv. (SPSS research and data analysis manual). Alinea Kiadó, Budapest, pp. 163-203.

Schmidt, R.H. \& RoDrick, G.E. (2003): Food safety handbook. John Wiley \& Sons Inc., Hoboken, NJ., p. 96.

Szabára, A. \& Ózsvári, L. (2010a): A salmonellosis elleni védekezés jelentősége és szabályozása - Irodalmi áttekintés - 1. rész. EU-szabályozás. (The significance of defense against salmonellosis and its regulation. Review. 1. EU regulation). Magy. Állatorvosok, 132(6), 333-340.

SzabÁrA, A. \& Ózsvári, L. (2010b): A salmonellosis elleni védekezés jelentősége és szabályozása - Irodalmi áttekintés -2 . rész. Nemzeti szabályozás. (The significance of defense against salmonellosis and its regulation. Review. 2. Hungarian regulation). Magy. Állatorvosok, 132(7), 398-408.

Szeitzné, Sz. M., KriszTalovics, K., Stréterné, L.Zs. FehÉr, Á. \& CSEH, J. (2008): Magyarország mikrobiológiai élelmiszer-biztonsági helyzete. (Microbiological food safety situation in Hungary). Élelmiszervizsgálati Közlemények, 54, 20-21.

VAJdA, Á., KASZA, G. \& MoHÁCSI-FarKas, Cs. (2019): Estimation of the occurence of foodborne salmonellosis in Hungary. Acta Alimentaria, 48, 96-104.

Open Access statement. This is an open-access article distributed under the terms of the Creative Commons Attribution 4.0 International License (https://creativecommons.org/licenses/by/4.0/), which permits unrestricted use, distribution, and reproduction in any medium, provided the original author and source are credited, a link to the CC License is provided, and changes - if any - are indicated. (SID_1) 